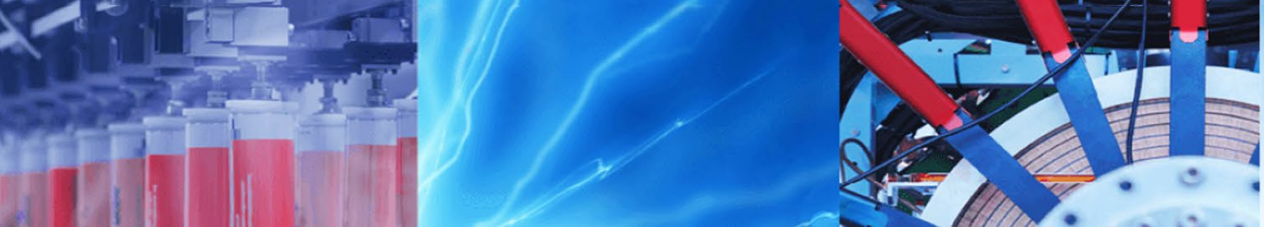

Research Article

\title{
Influence of heat curing and aggregates on the properties of phosphate-bonded biocomposites
}

\author{
Lehlohonolo Mngomezulu $^{1} \cdot$ Stephen Osakue Amiandamhen ${ }^{1} \cdot$ Martina Meincken $^{1} \cdot$ Luvuyo Tyhoda $^{1}$ (D)
}

Received: 30 April 2019 / Accepted: 17 October 2019 / Published online: 16 November 2019

(c) Springer Nature Switzerland AG 2019

\begin{abstract}
There is renewed effort in reducing the carbon footprint of conventional building materials by employing novel phosphate cements. This study investigates the influence of industrial aggregates, namely fly ash, silica fume and calcium carbonate on biocomposite properties. The biomaterials used included pine, bagasse and wattle. The density of the boards produced ranged from 0.82 to $1.16 \mathrm{~g} / \mathrm{cm}^{3}$, and the MOE ranged from 410.57 to $1737.87 \mathrm{MPa}$. The study concluded that biomass type, curing temperature and aggregates have significant effects on the biocomposite properties. The boards produced met the physical property requirements for use as non-load-bearing structures in humid and external conditions.
\end{abstract}

Keywords Biocomposites · Biomass · Silica fume · Fly ash · Calcium carbonate · Phosphate cement

\section{Introduction}

Magnesium phosphate cement (MPC) is a chemically bonded inorganic cementitious material made from the reaction of magnesium oxide $(\mathrm{MgO})$ and monopotassium dihydrogen phosphate $\left(\mathrm{KH}_{2} \mathrm{PO}_{4}\right)[1,2]$. It has a great potential in the development of composite products due to its ability to bind various materials together, either at room temperature or at elevated temperature [3]. It has excellent adhesion properties, which lead to high strength, fire and water absorption resistance in products $[2,4]$. Its mechanical and physical properties are comparable with those of Portland cement. MPC produced with fly ash has lower $\mathrm{CO}_{2}$ emission compared to cement $[1,4,5]$. In addition, the mining of phosphates consumes lower energy owing to the surface mining of phosphate rocks and the low temperature extraction of the ortho-phosphoric acid $\left(\mathrm{H}_{3} \mathrm{PO}_{4}\right)$ from the ore [6]. MPC also finds wide application in material repair and construction such as airport runway, bridges, highway pavements, etc., due to its superior mechanical properties as well as early strength development [7].

Chemically bonded phosphate cement can be made through the reaction of a metal oxide such as calcium oxide (CaO), calcium silicate $\mathrm{CaSiO}_{3}$ or magnesium oxide $(\mathrm{MgO})$ with monopotassium phosphate $\left(\mathrm{MKP} / \mathrm{KH}_{2} \mathrm{PO}_{4}\right)$ $[6,8]$. Residues from wood-based industries such as pulp mills, sawmills and agricultural processing industries have previously been utilised to manufacture MPC-bonded composite materials $[8,9]$. However, there are some aspects that need to be solved and understood regarding the products, including the bonding chemistry between phosphate cement and aggregates/fillers, as well as the type of biomass [10]. The incorporation of filler materials in the binder matrix reduces the hydrophilic properties of biomass by limiting the amounts of free hydroxyl groups in natural fibre-based composites [11]. This results in improved physical and mechanical properties, such as moisture resistance, fire resistance, thermal degradation resistance, modulus of elasticity (MOE) and modulus of rupture (MOR) [11, 12].

Luvuyo Tyhoda, Ityhoda@sun.ac.za | 'Department of Forest and Wood Science, Stellenbosch University, Cape Town, South Africa. 
Filler materials such as fly ash, silica fume and calcium carbonate are used in cement largely to improve the properties of cement. Further, this contributes to the recycling of a material considered as waste into marketable building materials as opposed to disposal in landfills [13]. Previous studies carried out by Rajamma et al. [14] and Amiandamhen et al. [8] have shown that up to $20 \%$ fly ash can be mixed with phosphate cement without negatively impacting the properties of the final product. While fly ash has been successfully demonstrated to improve cement properties, there is limited information on the performance of other filler materials such as silica fume, calcium carbonate or Kaolin in MPC-bonded composite products made of wood and bagasse fibres. Jiang et al. [15] reported that replacing phosphate cement with more than $5 \%$ of silica fume increases the expansion of mortar, which negatively affects the volume stability of the cement paste. However, there is no literature detailing on the use of silica fume as cement replacement on wood-based composite products.

Bentz et al. [16] suggested that calcium carbonate could also be considered as an alternative filler due to its sustainable supply as compared to fly ash and silica fume, which may be limited. Calcium carbonate is an inexpensive and abundant material found in sedimentary rock and improves properties of cement composites [17]. Current literature shows no record detailing the incorporation of calcium carbonate in phosphate-based cement as well as its performance on composite board products made of wood and fibre fibres. This study is therefore aimed at investigating the performance of board products prepared with MPC using calcium carbonate and silica fume in comparison to fly ash. Further, one of the advantages of phosphate-based cement is that they set at room temperature, thereby eliminating the need for additional energy inputs. However, Xiao et al. [11] argued that the preparation of composite products through pressing at elevated temperatures accelerates the solidification and strength development of the magnesium cement. Therefore, the current study also seeks to establish the influence of process parameters such as temperature on composite board properties.

There have been a number of studies on MPC-bonded composites for engineering applications. This study comes in a series of work conducted to evaluate the potential of manufacturing phosphate-bonded wood and fibre composite products. The novelty of this paper is that it presents an experimental evaluation of the influence of several factors including temperature, different filler and binder formulation on the properties of phosphate-bonded composite boards.

\section{Materials and methods}

\subsection{Wood waste and agricultural residues}

The biomaterial residues used included slash pine, black wattle and bagasse. Slash pine (Pinus elliottii) was supplied by Cape Pine Pty Ltd; a local subsidiary of the Global Environment Facility (GEF). Black wattle (Acacia mearnsii) was supplied by EC Biomass Fuel Pellets (Pty) Ltd, Port Elizabeth, South Africa. Sugarcane bagasse (Saccharum officinarum) was obtained from Illovo Sugar Ltd in South Africa.

\subsection{Binder}

The phosphate binder was produced from two products, namely magnesium oxide and monopotassium dihydrogen phosphate. The magnesium oxide used has the following chemical composition: assay $96 \%$ min; calcium $<1.1 \%$; iron $<0.05 \%$; acid insoluble substances $<0.1 \%$; free alkali and soluble salts $<2.0 \%$, heavy metals $<0.002 \%$; arsenic $<0.0003 \%$; loss on ignition $<10.0 \%$. The material was supplied by Macco Organiques, Czech Republic. Potassium phosphate monobasic is a soluble salt that is normally utilised in additives, fungicides and plant fertilisers. It was bought from Shijiazhuang Fertilizer Technologies Co. Ltd, China. Its chemical composition is: $\mathrm{KH}_{2} \mathrm{PO}_{4}>98 \%$; $\mathrm{P}_{2} \mathrm{O}_{5}>51.2 \% ; \mathrm{K}_{2} \mathrm{O}>33.5 \%$; chloride $<0.2 \%$; water insoluble $<0.2 \%$; moisture $<1.0 \%$.

\subsection{Filler materials}

Fly ash was supplied by Ulula Ash, South Africa. It originated from coal combustion plants, and its chemical composition is $\mathrm{SiO}_{2}<60 \%$; $\mathrm{Al}_{2} \mathrm{O}_{3}<35 \%$; $\mathrm{CaO}<10 \%$; $\mathrm{MgO}<5 \%$; $\mathrm{Fe}_{2} \mathrm{O}_{3}<5 \% ; \mathrm{TiO}_{2}$. Calcium carbonate $\left(\mathrm{CaCO}_{3}\right)$ was supplied by Kimix Chemical and Lab Supplies Co, South Africa. Its chemical composition is assay min $99.5 \%$, chloride 0.001 , heavy metal $0.0005 \%$ and sulphate $0.005 \%$. Silica fume, also known as micro-silica, is an ultrafine powder that is collected as the waste from the production of silicon and ferrosilicon alloys. It was supplied by MAPEI South Africa (Pty) Ltd with silica sand $<0.1 \%$.

\subsection{Biomass and binder preparation}

The biomaterial residues were chipped and hammermilled through a 1-mm sieve. The milled samples were conditioned at $20^{\circ} \mathrm{C}$ and $65 \%$ relative humidity (RH) for $24 \mathrm{~h}$ before board production according to BS EN 634-2 
Table 1 Independent variables and levels for the central composite design

\begin{tabular}{lccr}
\hline Variables & \multicolumn{2}{c}{ Levels } & \\
\cline { 2 - 4 } & Low & Medium & High \\
\hline $\mathrm{KH}_{2} \mathrm{PO}_{4}: \mathrm{MgO}$ & 1 & 3 & 5 \\
Filler content $(\%)$ & 10 & 20 & 30 \\
Temperature $\left({ }^{\circ} \mathrm{C}\right)$ & 20 & 85 & 150 \\
\hline
\end{tabular}

[18]. The equilibrium moisture content of the biomaterials was $7 \%$. Dead-burned magnesium oxide $(\mathrm{MgO})$ and potassium dihydrogen phosphate $\left(\mathrm{KH}_{2} \mathrm{PO}_{4}\right)$ were mixed together in a w/w ratio according to Table 1.

\subsection{Board formation}

The boards were prepared according to a method previously described by Amiandamhen et al. [8]. According to this method, the conditioned biomass samples were mixed with binder and filler as shown in Table 1. The biomass amount was kept constant at $80 \mathrm{~g}(36.71 \%)$ in all boards. A predetermined amount of water was added, and mixing of all the components was done until a homogenous paste was formed. The amount of water added was calculated as described by Sotannde et al. [19] (Eq. 1).

$W=B+(\mathrm{FSP}-\mathrm{MC}) \times F$

where $W=$ amount of water $(\mathrm{ml}), B=$ inorganic components $(\mathrm{g}), \mathrm{FSP}=$ fibre saturation point $(\%), \mathrm{MC}=$ moisture content (\%) and $F=$ biomaterial (g).

The mixture was poured into a steel mould measuring $218 \times 77 \times 40 \mathrm{~mm}$ and pressed at $200 \mathrm{kPa}$ for $5 \mathrm{~min}$ at the corresponding temperature based on the experimental design. After demoulding, the boards were allowed to cure at ambient temperature for $24 \mathrm{~h}$. Subsequently, they were conditioned at $20^{\circ} \mathrm{C}$ and $65 \% \mathrm{RH}$ for $96 \mathrm{~h}$ before testing.

\subsection{Boards testing}

The conditioned boards were tested for modulus of rupture (MOR), modulus of elasticity (MOE), density, water absorption (WA) and thickness swelling (TS). The aim of the tests was to investigate the effect of binder ratio, filler content and temperature on the physical and mechanical properties of the resulting boards. Flexural strength test was conducted on an Instron testing machine fitted with a $250 \mathrm{kN}$ load cell. The machine was set to apply load continuously throughout the test at a rate of $5 \mathrm{~mm} / \mathrm{min}$. The maximum load of deflection at the first failure was recorded, and MOR and MOE were calculated according to BS EN 634-2 [18].
The dimensional stability of the boards was evaluated in terms of water absorption (WA) and thickness swelling (TS). For the test, the samples were cut with a saw into $75 \times 50 \mathrm{~mm}$ dimensions. WA and TS tests were carried out by weighing and measuring the thickness of the dryconditioned sample and submerging in water for $24 \mathrm{~h}$ [20]. After submersion, the samples were removed and drained at ambient temperature for $10 \mathrm{~min}$. Thereafter, they were re-weighed, and the dimensions re-measured. The absorbed water and thickness swelling were calculated and expressed as a percentage.

\subsection{Experimental design}

The experiment was designed according to a central composite design (CCD) as given in Table 1. A central composite design (CCD) is an experimental design useful in developing a second-order model for the response variable without the need to use a complete three-level factorial experiment. A CCD consists of three distinct sets of experimental runs, which include a factorial design, a set of centre points and a set of axial points. The design is useful in response surface methodology to predict the outcome of a response by considering the independent variables on a surface plot.

The CCD consisted of three variables, namely percentage filler material based on the total binder content, temperature and binder ratio $\left(\mathrm{KH}_{2} \mathrm{PO}_{4} / \mathrm{MgO}\right)$. The mass of the biomass was fixed (based on previous experiments). This design was maintained for each wood/fibre material. The variables were coded at three levels, $-1,0$ and 1 , representing the low, middle and high levels (Table 1). The number of experiments $(N)$ required for the development of the CCD is defined by the relationship outlined by Ahmadi et al. [21] as

$N=2^{k-p}+2 k+C p$

where $k$ is the number of factors, $C p$ is the number of centre points and fractionalisation element $p=0$ for a full design. In this study, the experiment was designed to give a total number of 16 runs, 1 block, 3 replicates for each factor The statistical relationship between experimental variables and responses was determined using the response surface methodology (RSM), which helps to predict optimum experimental conditions for an optimum product performance.

\subsection{Statistical analysis}

Statistical analysis was performed using the software program Statistica ex Statsoft, Dell Inc., Tulsa, OK, USA. Analysis of variance (ANOVA) was used to determine the 
variable(s) that were significant on the board properties and to determine the effects of different variables on the physical and mechanical properties of the particleboards. The overall contribution of each variable to the panel property was studied by Pareto chart, which are useful in cases of limited numbers of variables that produce a significant overall effect [22]. The adequacy and fitness of the developed polynomial models were tested by regression analysis.

\section{Results and discussion}

\subsection{Panel properties}

Tables 2, 3 and 4 show the average test results obtained based on the experimental design. It is evident that calcium carbonate used as a filler material resulted in overall

Table 2 Physical and mechanical properties of boards, using fly ash as filler

\begin{tabular}{lrrrl}
\hline Properties & Pine & Bagasse & Black wattle & $\begin{array}{l}\text { Standard } \\
\text { (EN 634-2) }\end{array}$ \\
\hline Density $\left(\mathrm{g} / \mathrm{cm}^{3}\right)$ & 0.94 & 0.82 & 1.14 & 1 \\
WA (\%) & 24.14 & 48.42 & 18.45 & 35 \\
TS (\%) & 2.37 & 4.18 & 0.55 & 1.5 \\
MOR (MPa) & 3.37 & 2.83 & 4.37 & 9 \\
MOE (MPa) & 1131.36 & 410.57 & 1282.24 & 4000 \\
\hline
\end{tabular}

Table 3 Physical and mechanical properties of board, using silica fume as filler

\begin{tabular}{lrrrl}
\hline Properties & \multicolumn{1}{l}{ Pine } & Bagasse & Black wattle & $\begin{array}{l}\text { Stand- } \\
\text { ard (EN } \\
634-2)\end{array}$ \\
\hline Density $\left(\mathrm{g} / \mathrm{cm}^{3}\right)$ & 0.93 & 0.85 & 1.16 & 1 \\
WA (\%) & 27.32 & 45.23 & 18.32 & 35 \\
TS (\%) & 1.75 & 3.15 & 0.35 & 1.5 \\
MOR (MPa) & 3.03 & 3.45 & 3.77 & 9 \\
MOE (MPa) & 1194.34 & 542.33 & 927.47 & 4000 \\
\hline
\end{tabular}

Table 4 Physical and mechanical properties of board, using calcium carbonate as filler

\begin{tabular}{lrrrl}
\hline Properties & Pine & Bagasse & Black wattle & $\begin{array}{l}\text { Stand- } \\
\text { ard (EN } \\
634-2)\end{array}$ \\
\hline Density $\left(\mathrm{g} / \mathrm{cm}^{3}\right)$ & 0.95 & 0.99 & 1.21 & 1 \\
WA (\%) & 31.01 & 30.63 & 15.77 & 35 \\
TS (\%) & 1.33 & 3.40 & 0.45 & 1.5 \\
MOR (MPa) & 3.36 & 4.05 & 6.16 & 9 \\
MOE (MPa) & 959.14 & 697.68 & 1731.87 & 4000 \\
\hline
\end{tabular}

better properties than fly ash and silica fume. Further, the results show that black wattle resulted in superior properties than other biomass types. The minimum density requirement for cement-bonded particleboard products is $1 \mathrm{~g} / \mathrm{cm}^{3}$ according to British Standard [18]. The particleboards manufactured from black wattle and the three filler materials (fly ash, silica fume and calcium carbonate), respectively, met this requirement according to the standard. The respective densities of the boards were 1.14, 1.16 and $1.21 \mathrm{~g} / \mathrm{cm}^{3}$. Based on this standard, the boards produced from pine and bagasse residues with individual filler materials did not meet the density requirement.

The results further show that some composite boards met the requirement for WA, while others have a higher WA than the allowed maximum value of $25 \%$. Boards produced with sugarcane bagasse and the three different fillers, respectively, have WA values exceeding the maximum limit. On the other hand, boards produced with pine and fly ash met the requirements, while those produced with silica fume and calcium carbonate have WA values that were higher than the allowable limit. Black wattle boards bonded with phosphate cement and the different fillers, respectively, perform best with regard to WA (Tables 2, 3 and 4). This was followed by TS of the same biomaterial. According to Yazaki et al. [23], black wattle has a high tannin content, which is an important source of adhesive and can act as a water-proofing material. Pine boards produced with $\mathrm{CaCO}_{3}$ also met the cement-bonded particleboard requirements for TS, but there was no significant interaction between the variables.

\subsection{Effect of processing variables on the properties of the composite boards}

The analysis of variance (ANOVA) was used to analyse the effects of all the independent variables on the properties of the particleboard (Tables 5, 6 and 7). The results show that the binder ratio, filler content and temperature have significant influence on the properties of the boards $(p<0.05)$. Thereafter, response surface methodology (RSM) was used to show the interaction between variables and predict desired board properties.

\subsubsection{Density}

The Pareto chart and fitted response surface show that the fly ash content and temperature significantly affect the density of the pine boards (Fig. 1a). The significant interaction of fly ash and temperature with a binder ratio of 5:1 shows that an increase in temperature above $60^{\circ} \mathrm{C}$ and fly ash content above $15 \%$ decreases the density of the pine boards. This is because an increase in fly ash content above 
Table 5 ANOVA of the effect of binder ratio on the measured properties of the composite boards

\begin{tabular}{|c|c|c|c|c|c|c|c|c|c|}
\hline \multirow[t]{2}{*}{ Properties } & \multicolumn{3}{|l|}{ Fly ash } & \multicolumn{3}{|c|}{ Silica fume } & \multicolumn{3}{|c|}{ Calcium carbonate } \\
\hline & Pine & Bagasse & B. Wattle & Pine & Bagasse & B. wattle & Pine & Bagasse & B. wattle \\
\hline Density & $0.044^{*}$ & $0.046^{*}$ & 0.665 & 0.079 & 0.121 & 0.084 & $0.003^{*}$ & 0.077 & $0.026^{*}$ \\
\hline WA & 0.256 & $0.008^{*}$ & $0.012^{*}$ & 0.342 & 0.119 & $0.037^{*}$ & 0.372 & $0.011^{*}$ & $0.021^{*}$ \\
\hline TS & 0.720 & 0.351 & 0.127 & 0.108 & 0.154 & 0.104 & 0.075 & 0.475 & 0.371 \\
\hline MOR & $0.007^{*}$ & 0.077 & $0.020^{*}$ & 0.197 & $0.010^{*}$ & 0.248 & 0.993 & 0.141 & 0.069 \\
\hline MOE & $0.013^{*}$ & $0.040^{*}$ & $0.011^{*}$ & 0.212 & $0.010^{*}$ & 0.391 & 0.916 & 0.762 & 0.186 \\
\hline
\end{tabular}

*Significant values at $p<0.05$

\begin{tabular}{|c|c|c|c|c|c|c|c|c|c|}
\hline \multirow[t]{2}{*}{ Properties } & \multicolumn{3}{|l|}{ Fly ash } & \multicolumn{3}{|c|}{ Silica fume } & \multicolumn{3}{|c|}{ Calcium carbonate } \\
\hline & Pine & Bagasse & B. Wattle & Pine & Bagasse & B. Wattle & Pine & Bagasse & B. Wattle \\
\hline Density & 0.117 & 0.148 & 0.360 & 0.430 & 0.206 & 0.195 & 0.911 & 0.087 & 0.319 \\
\hline WA & 0.132 & $0.034^{*}$ & 0.284 & 0.641 & 0.168 & 0.052 & 0.245 & $0.008^{*}$ & $0.001^{*}$ \\
\hline TS & 0.155 & 0.202 & 0.962 & 0.580 & 0.162 & 0.971 & 0.055 & 0.410 & 0.203 \\
\hline MOR & $0.035^{*}$ & 0.982 & 0.335 & 0.981 & $0.014^{*}$ & $0.043^{*}$ & 0.458 & 0.145 & 0.788 \\
\hline MOE & 0.270 & $0.047^{*}$ & $0.032^{*}$ & 0.204 & $0.006^{*}$ & 0.365 & 0.937 & 0.706 & 0.931 \\
\hline
\end{tabular}

*Significant values at $p<0.05$

\begin{tabular}{|c|c|c|c|c|c|c|c|c|c|}
\hline \multirow[t]{2}{*}{ Properties } & \multicolumn{3}{|l|}{ Fly ash } & \multicolumn{3}{|c|}{ Silica fume } & \multicolumn{3}{|c|}{ Calcium carbonate } \\
\hline & Pine & Bagasse & B. Wattle & Pine & Bagasse & B. Wattle & Pine & Bagasse & B. Wattle \\
\hline Density & 0.084 & 0.097 & 0.394 & 0.364 & 0.166 & 0.140 & 0.440 & 0.120 & 0.419 \\
\hline WA & 0.077 & $0.007^{*}$ & 0.081 & 0.219 & 0.116 & $0.034^{*}$ & 0.318 & $0.007^{*}$ & $0.002^{*}$ \\
\hline TS & 0.078 & 0.966 & 0.992 & 0.312 & 0.097 & 0.708 & 0.362 & 0.405 & 0.766 \\
\hline MOR & $0.012^{*}$ & 0.071 & 0.079 & 0.092 & $0.008^{*}$ & $0.047^{*}$ & 0.863 & 0.128 & 0.085 \\
\hline MOE & $0.034^{*}$ & $0.038^{*}$ & 0.080 & 0.054 & $0.003^{*}$ & 0.706 & 0.951 & 0.297 & 0.678 \\
\hline
\end{tabular}

*Significant values at $p<0.05$
Table 6 ANOVA of the effect of temperature on the measured properties of the composite boards
Table 7 ANOVA of the effect of filler content on the measured properties of the composite boards
$15 \%$ of the mass of the board increases the volume of the board without contributing to strength and density. The same results were observed by Amiandamhen et al. [8]. Figure $1 \mathrm{~b}$ also shows that there is a significant interaction between temperature and binder ratio on the density of pine boards. An increase in binder ratio and temperature at a fly ash content of $10 \%$ increases the density of the pine boards. The increase in binder ratio increases the formation of basic building block of the ceramic, which increases density of the particleboards [24]. In addition, there is a significant effect of fly ash and temperature on the density of bagasse boards. The response surface plot shows that fly ash and temperature have the same effect on bagasse board as in pine board (Fig. 1)

\subsubsection{Water absorption (WA)}

The interaction between binder ratio and temperature has a significant influence on WA of the black wattle bonded board. Figure 2 shows how binder ratio and temperature (with $20 \%$ of silica fume filler) affect black wattle board properties. Increasing the temperature to $160^{\circ} \mathrm{C}$ has a little influence on WA. However, increasing the binder ratio to 3:1 reduces the WA of the produced particleboards, but adding more binder increases WA. The optimum binder ratio for WA resistance in black wattle boards was found to be 3:1.

Furthermore, the interaction of $\mathrm{CaCO}_{3}$, binder ratio and temperature influences the WA of pine board (Fig. 3). The result shows that a decrease in WA appears with increasing $\mathrm{CaCO}_{3}$ and binder ratio at $150^{\circ} \mathrm{C}$. This may be due to the reaction of phosphate cements with $\mathrm{CaCO}_{3}$ that forms a hard core-bonded hydrated product, which is water resistant [1]. In addition, the temperature and $\mathrm{CaCO}_{3}$ at a binder ratio of 3:1 have a significant effect on pine boards (Fig. 3b). The result shows that an increase in $\mathrm{CaCO}_{3}$ above $15 \%$ decreases WA at a temperature range between 40 and $140{ }^{\circ} \mathrm{C}$. The decreased WA due to a high $\mathrm{CaCO}_{3}$ content is related to the reaction between acid phosphate and alkaline carbonate. The acid phosphate $\left(\mathrm{KH}_{2} \mathrm{PO}_{4}\right)$ in aqueous 


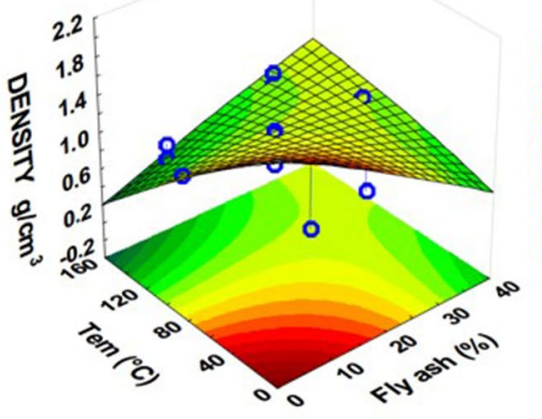

(a)

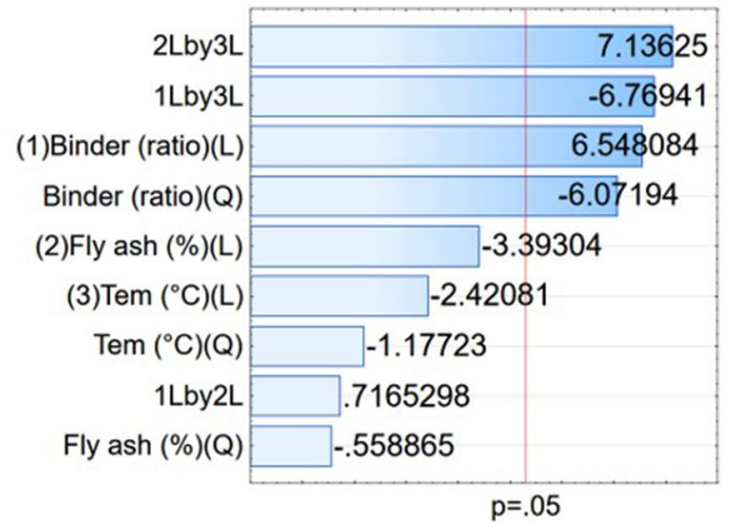

(b)
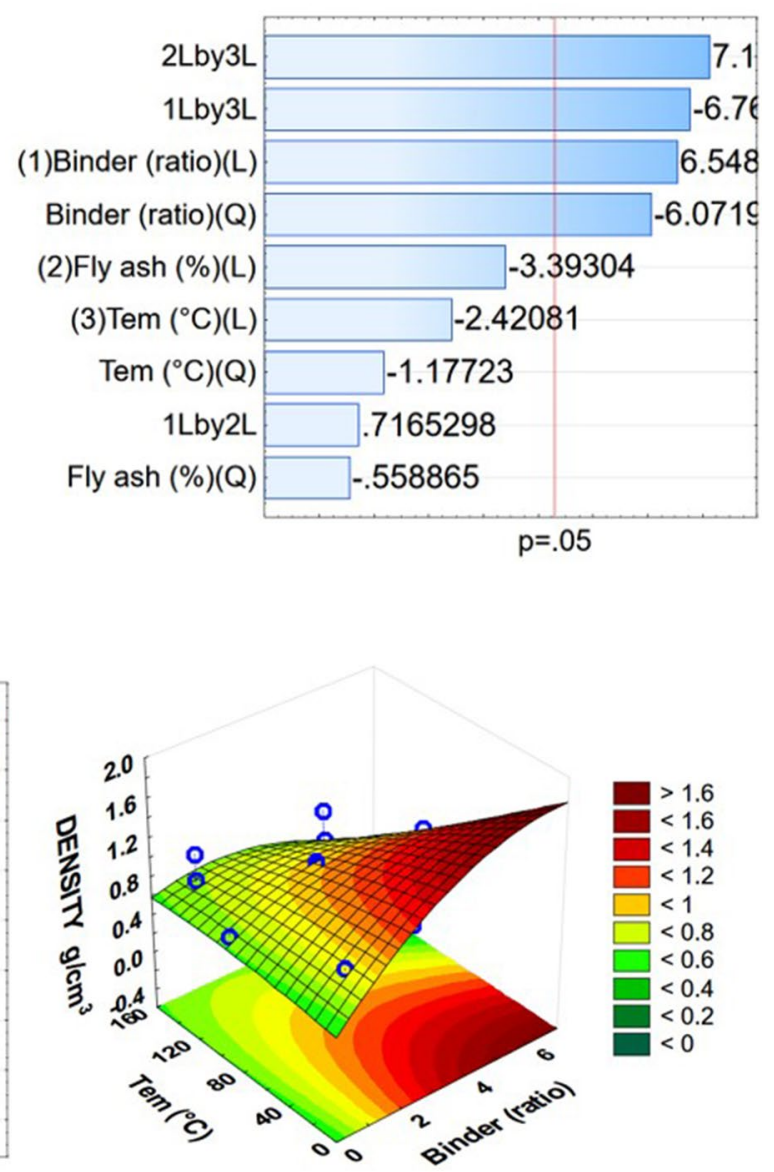

Fig. 1 Pareto charts and response surface plots showing the influence of independent variables on density of a pine and $\mathbf{b}$ bagasse boards
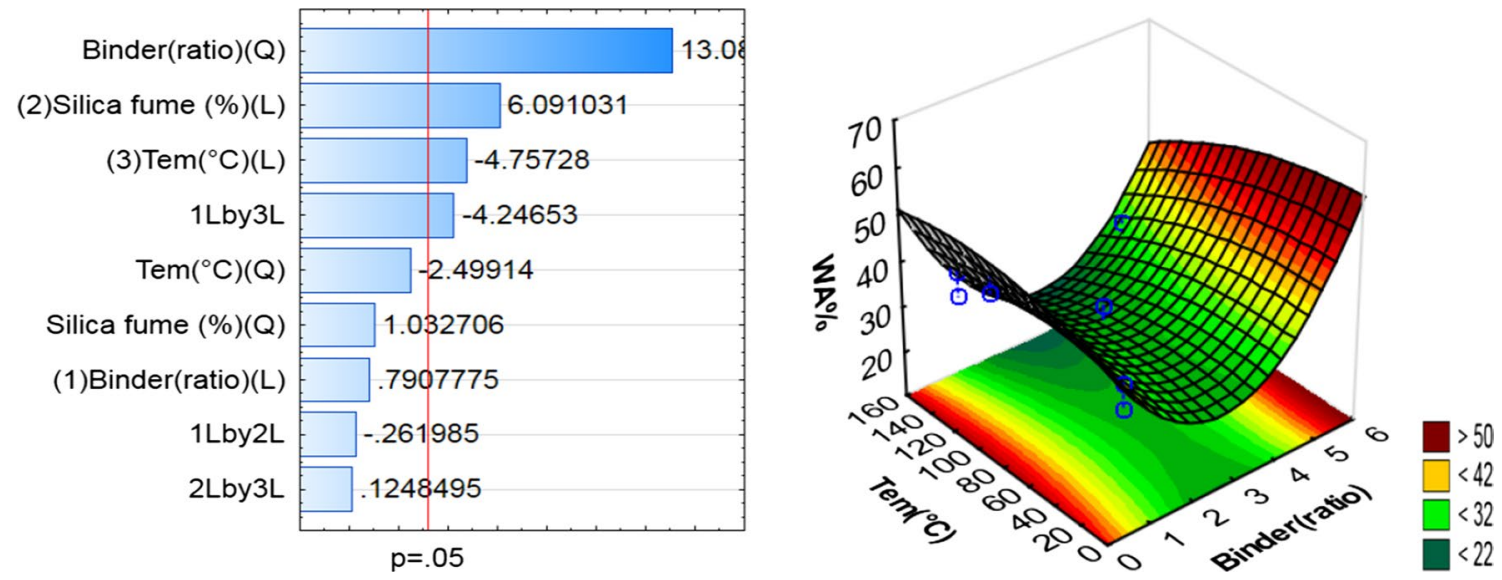

Fig. 2 Pareto chart and response surface showing the influence of independent variables on WA of black wattle boards

solution releases phosphate anions, which increases the solubility of the alkaline component $\left(\mathrm{CaCO}_{3}\right)$. This allows more $\mathrm{CaCO}_{3}$ to dissolve in the $\mathrm{KH}_{2} \mathrm{PO}_{4}$ solution and results in the formation of a chemically bonded phosphate cement, which is resistant to water penetration, as observed by [1]. Bagasse-bonded particleboards show the 

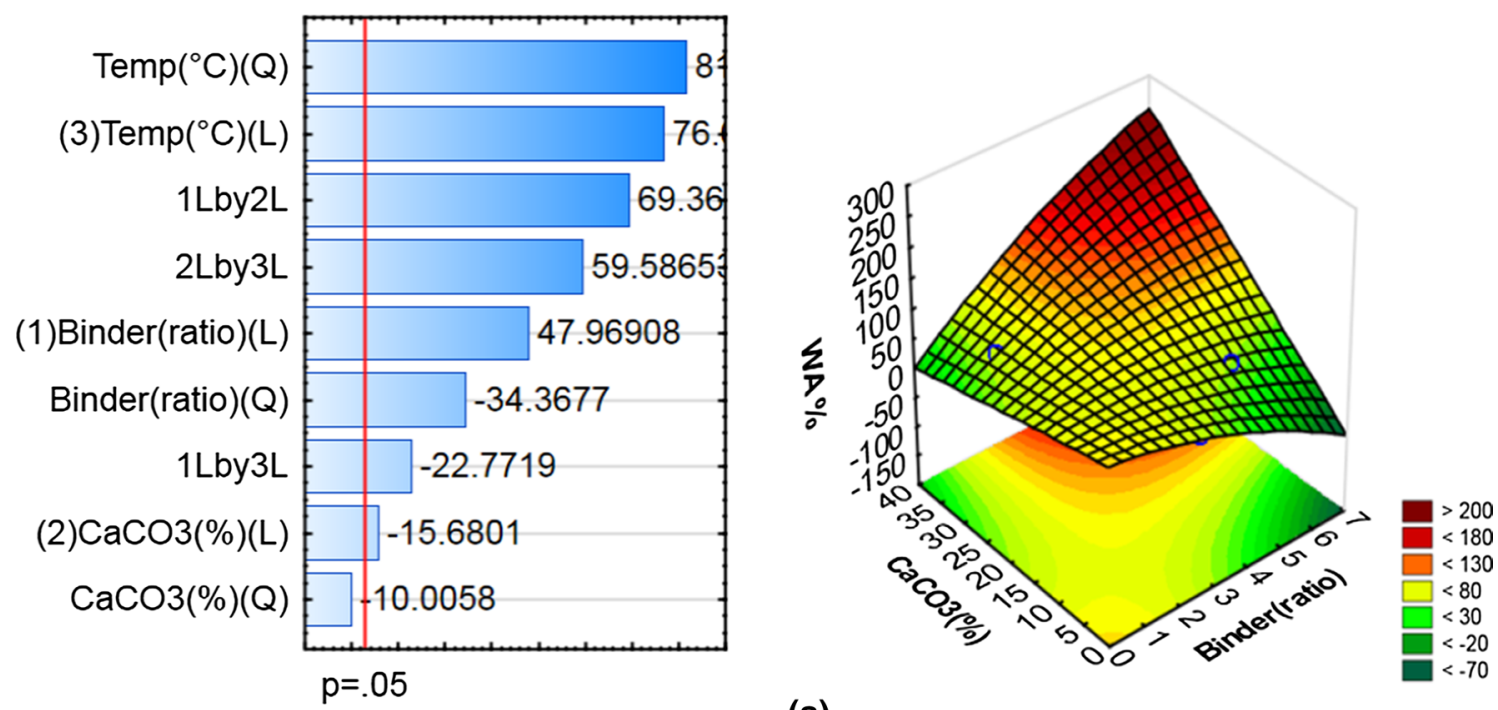

(a)

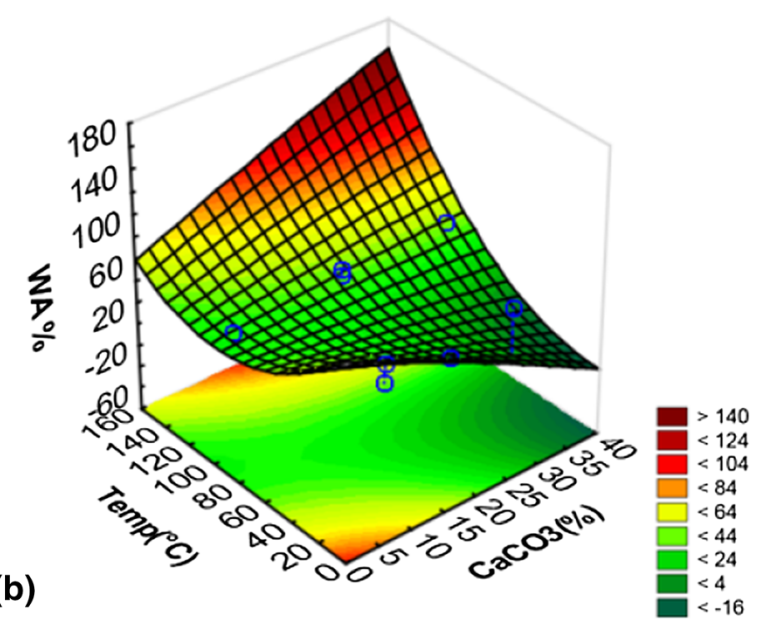

Fig. 3 Pareto chart and response surfaces showing the influence of independent variables on WA of pine boards and bagasse boards

same results as pine boards, with a significant interaction between binder ratio and $\mathrm{CaCO}_{3}$ at $150^{\circ} \mathrm{C}$.

\subsubsection{Modulus of rupture (MOR) and modulus of elasticity (MOE)}

The minimum requirement for the MOR of cementbonded particleboard is $9 \mathrm{MPa}$ and $4000 \mathrm{MPa}$ in class II boards for the MOE [1]. MOR is the measure of the maximum bending load that a material can withstand, while MOE is the measure of the stiffness of the board that gives the deflection from the applied load. From the results, the particleboards produced with bagasse and fly ash have the lowest MOR of $2.83 \mathrm{MPa}$ and MOE of $410.57 \mathrm{MPa}$. The highest bending strength was recorded for the boards made of black wattle and calcium carbonate with MOR of $6.16 \mathrm{MPa}$ as well as the highest MOE of $1731.87 \mathrm{MPa}$. These high values can be attributed to the absence of void space in the particleboard, which enhances strength. The high mechanical strength of the board may be due to the calcium carbonate in magnesium potassium phosphate cement, which improves the early hydration degree and crystallisation in the board [25].

Figure $4 a$, $b$ shows the significant interaction between binder ratio and temperature on the MOR and MOE of pine boards, respectively. An increase in binder ratio increases MOR and MOE with a fly ash content of $10 \%$, and a change in temperature did not change the MOR and MOE largely. This is due to the exothermic reaction of acid phosphate with alkaline oxides, which does not depend on temperature to set [26].

Figure 5 shows the significant interaction between binder and fly ash content on the MOE of bagasse board at room temperature $\left(20^{\circ} \mathrm{C}\right)$. The fitted response surface shows that an increase in fly ash beyond $25 \%$ decreases the MOE of the bagasse board. Although the chemistry 

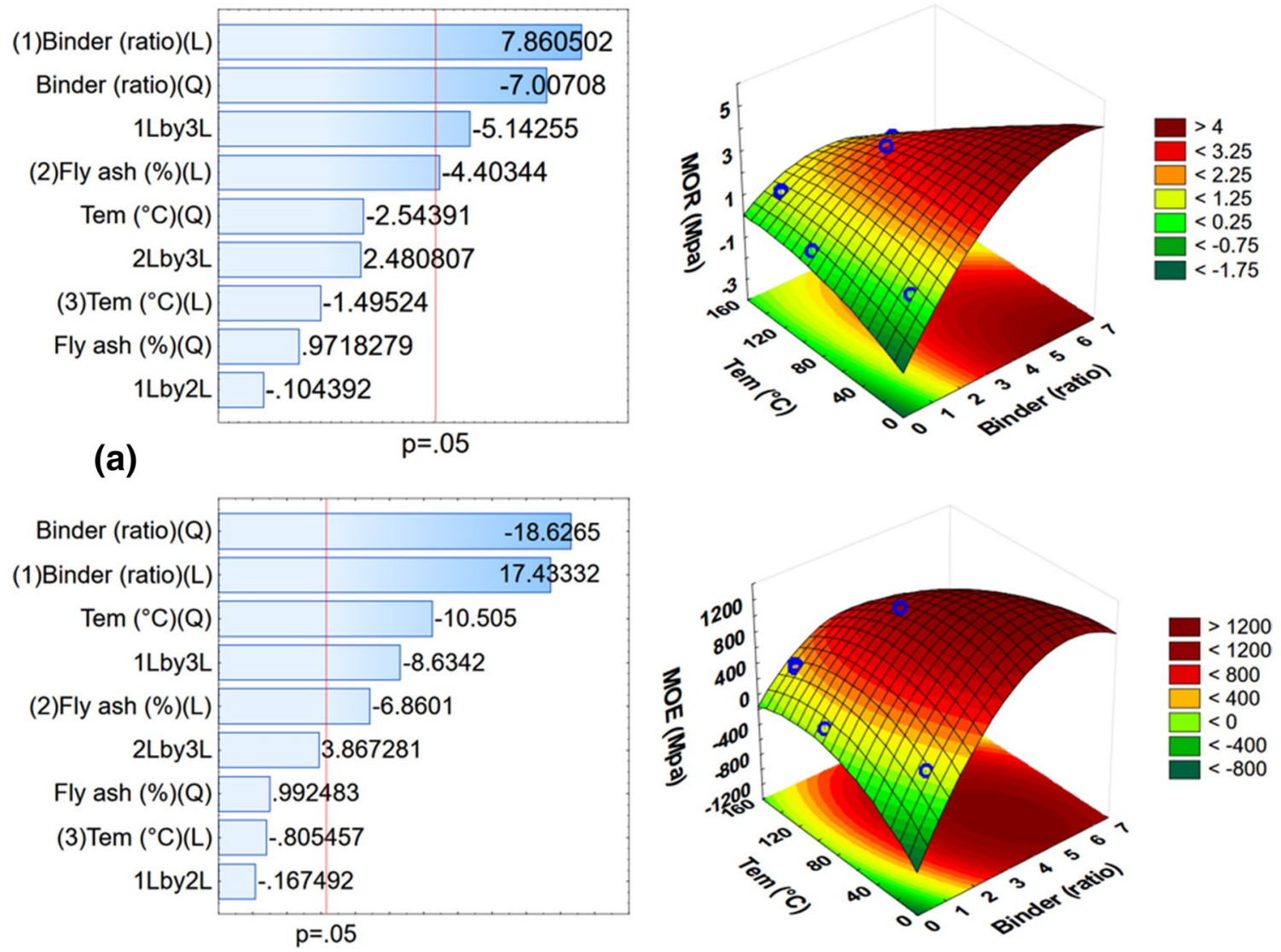

(b)

Fig. 4 Pareto charts and response surfaces showing the influence of independent variables on a MOR and $\mathbf{b}$ MOE of pine boards
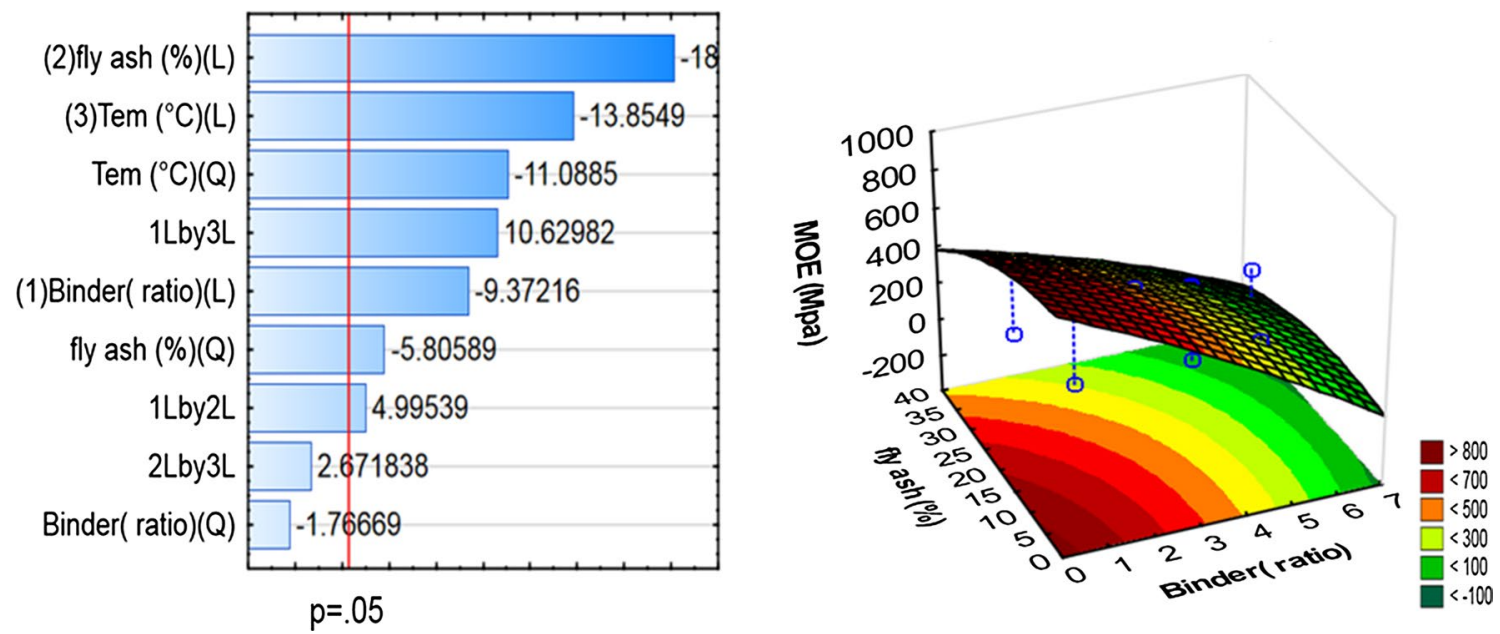

Fig. 5 Pareto chart and response surface showing the influence of independent variables on MOE of bagasse boards

between fly ash and magnesium potassium phosphate cement is not well understood, $X u$ et al. [27] revealed that using a high fly ash content in phosphate cement reactions results in poor composite strength.
The MOR of bagasse board is influenced by the interaction between binder and temperature, as well as silica fume and temperature (Fig. 6a). Taking into account the relationship between silica fume and temperature on 

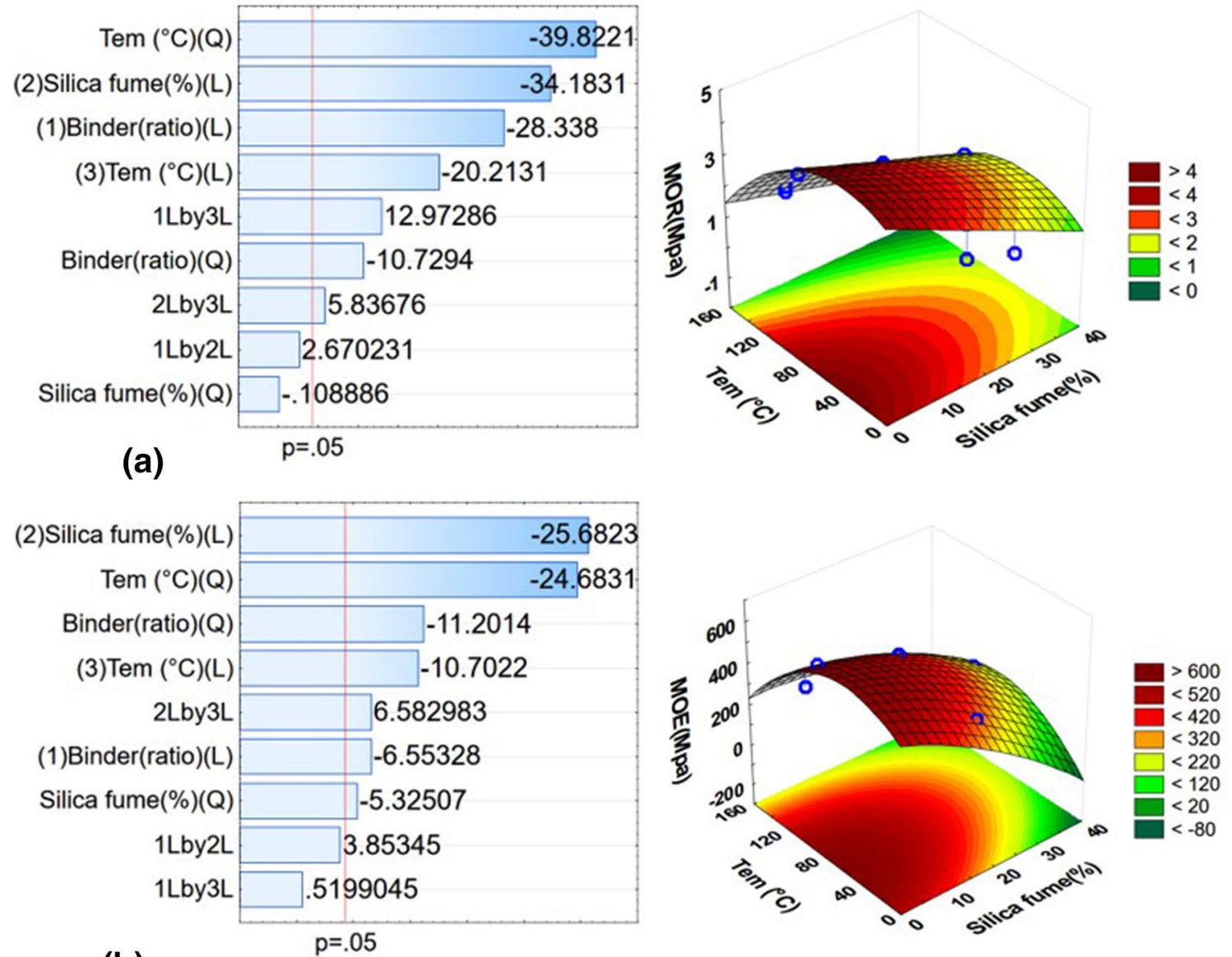

(b)

Fig. 6 Pareto charts and response surfaces showing the influence of independent variables on a MOR and $\mathbf{b}$ MOE of bagasse boards

MOR of bagasse particle board, the figure shows that the increase of temperature beyond $120^{\circ} \mathrm{C}$ and silica fume over $15 \%$ at a binder ratio of 3:1 decreases MOR. The same applies to the MOE of bagasse boards (Fig. 6b). Silica fume is a very reactive pozzolanic material, like volcanic ash, and has the ability to improve the mechanical properties of cement mortar. However, the addition of silica fume above $15 \%$ decreases mechanical properties. This is because of the partly densification of the interfacial zone between cement and silica fume as observed by Chung [28].

The replacement of the phosphate binder with 10, 20 and $30 \%$ of silica fume in pine boards has a significant effect on MOE (Fig. 7). Based on the fitted response surface, an increase in temperature and silica fume content to $15 \%$ at a fixed binder ratio of 3:1 increases the MOE of pine board. The higher temperature increases the distribution of the binder between pine particles to the interfacial zone; hence, the bonding reaction is improved, which resulted in increased MOE. Figure $7 \mathrm{~b}$ shows the effect of binder and silica fume interaction on the MOE of pine board. An increase in binder ratio up to 5:1 and silica fume to $15 \%$ increases the MOE of the pine board. The improvement of MOE when silica fume is added below $15 \%$ may be due to the effect of the fine particles, which fill the spaces between the binder particles. In addition, the chemical reaction of silica fume in hydrated cements improves mechanical properties due to its larger surface area and amount of amorphous silica. However, the addition of silica fume above $15 \%$ decreases mechanical properties because of the high degree of crystallisation. This results to high porosity that reduces the strength of the particle board [29].

\subsection{Influence of biomaterial type on board properties}

The biomaterial content in this research was kept constant (36.76\%) to evaluate the influence of independent variables on board properties. The Pareto charts plotted for black wattle particleboard show no significant interaction between the independent variables (filler 
Fig. 7 Pareto chart and response surfaces showing the influence of independent variables on MOE of pine boards
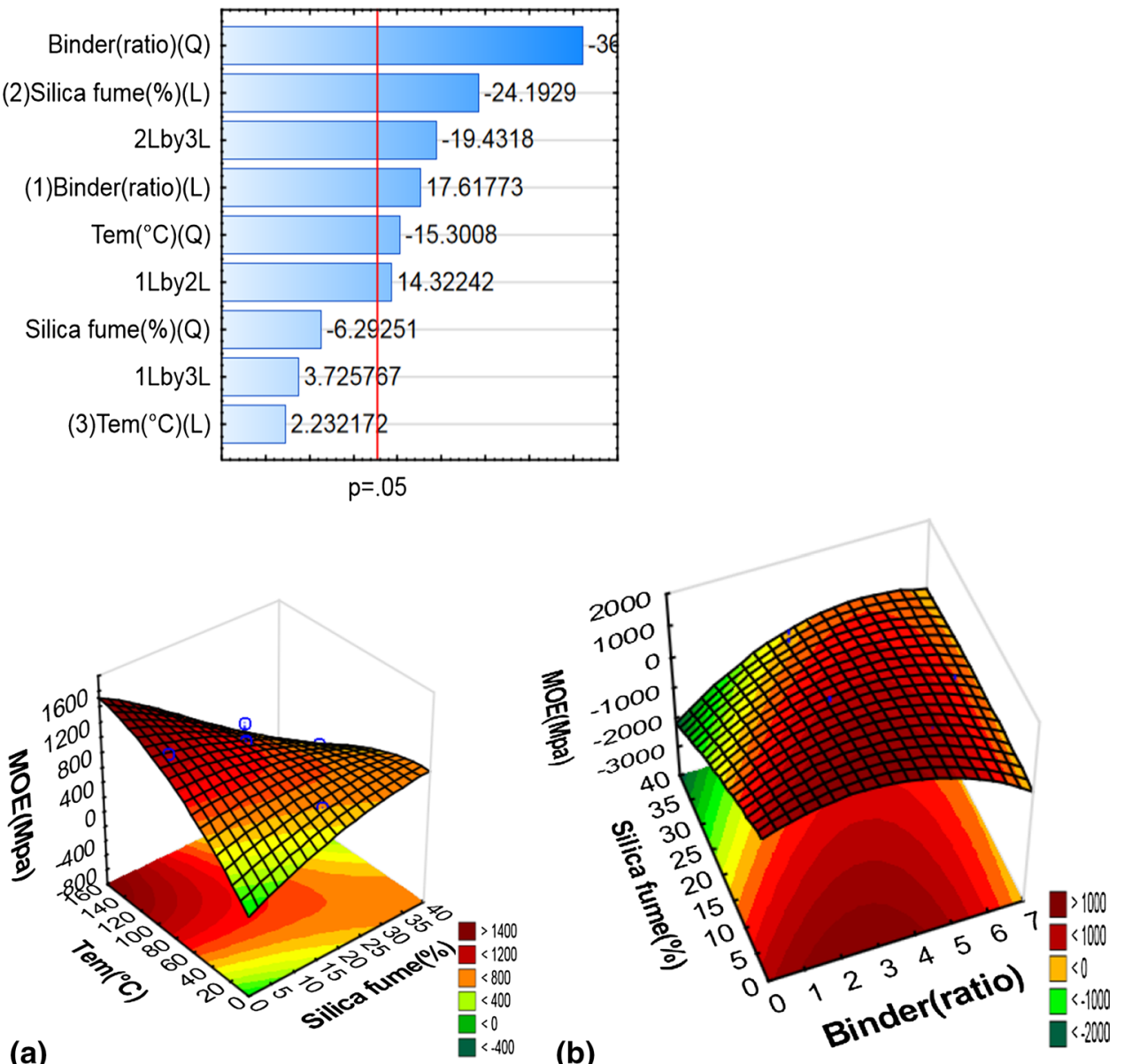

(b)

wattle, such as high tannin content, which influenced the properties of the board. Tannin is the natural polyphenol that is sticky when condensed, and it is resistant to water penetration. It is extracted from different plants and can be used as environmentally friendly adhesives. Kim [30] used natural tannin as alternative adhesives to formaldehyde-based resin to minimise the emission of volatile organic compounds in production of composite materials.

\section{Conclusions}

The study proposed adding value to waste by transforming lesser value materials into high performance, eco-friendly, low-cost and improved phosphate-bonded particleboards. The variables used, i.e., filler materials, binder ratio and processing temperature in this study, showed significant influences on the particleboard properties. The boards produced with $\mathrm{CaCO}_{3}$ filler showed superior properties compared to boards produced with fly ash and silica fume. This was triggered by the reaction 
of $\mathrm{CaCO}_{3}$ with $\mathrm{KH}_{2} \mathrm{PO}_{4}$, which allow $\mathrm{CaCO}_{3}$ to dissolve in the $\mathrm{KH}_{2} \mathrm{PO}_{4}$ 's solution and form a chemically bonded phosphate cement. However, in order for pine board to be resistant to $\mathrm{WA}, \mathrm{CaCO}_{3}$ content lower than $15 \%$ and temperature in the range of $40-140{ }^{\circ} \mathrm{C}$ should be utilised in the production of the composite boards.

Furthermore, the upper limit for the addition of fly ash was estimated at $15 \%$. This proved to substitute the phosphate cement without the deterioration of the pine and bagasse boards' density at a temperature lower than $85^{\circ} \mathrm{C}$. Replacing cement with a maximum amount of $25 \%$ fly ash resulted in a high MOE in bagasse boards. Silica fume gave the highest MOR and MOE in bagasse boards when up to $15 \%$ is used with a temperature below $120^{\circ} \mathrm{C}$. The same amount of silica fume also improved the MOE of pine board. The density, WA and TS of black wattle boards produced with all three different filler material (fly ash, silica fume and calcium carbonate) met the minimum requirements for cementbonded particleboard standards. This allows the conclusion that boards produced with black wattle wood residues resulted in improved board properties due to its high tannin content. High temperatures up to $140{ }^{\circ} \mathrm{C}$ are important to activate tannin and distribute adhesives around the biomaterial particles.

Acknowledgement The first author is grateful to the National Research Foundation, South Africa (Grant No. 20693), for the scholarship.

\section{Compliance with ethical standard}

Conflict of interest There is no conflict of interest associated with this publication.

\section{References}

1. Wagh AS (2013) Recent progress in chemically bonded phosphate ceramics. ISRN Ceram 2013:1-20

2. Amiandamhen SO, Montecuccoli Z, Meincken M, Barbu MC, Tyhoda L (2018) Phosphate bonded wood composite products from invasive Acacia trees occurring on the Cape Coastal plains of South Africa. Eur J Wood Wood Prod 76(2):437-444

3. Amiandamhen SO (2017) Phosphate bonded wood and fibre composites. Stellenbosch University, Stellenbosch

4. Lloyd RR, Provis JL, Van Deventer JSJ (2009) Microscopy and microanalysis of inorganic polymer cements. 1: remnant fly ash particles. J Mater Sci 44(2):608-619

5. Hong LT, Lubell AS (2015) Phosphate cement-based concretes containing silica fume. ACI Mater J 112(4):587-596

6. Wagh AS (2004) Chemically bonded phosphate ceramics, 1 st edn. Elsevier, London

7. Fang Y, Cui P, Ding Z, Zhu J (2018) Properties of a magnesium phosphate cement-based fire-retardant coating containing glass fiber or glass fiber powder. Constr Build Mater 162:553-560
8. Amiandamhen SO, Meincken M, Tyhoda L (2016) Magnesium based phosphate cement binder for composite panels: a response surface methodology for optimisation of processing variables in boards produced from agricultural and wood processing industrial residues. Ind Crops Prod 94:746-754

9. Amiandamhen SO, Meincken M, Tyhoda L (2018) The effect of chemical treatments of natural fibres on the properties of phosphate-bonded composite products. Wood Sci Technol 52(3):653-675

10. Hajimohammadi A, van Deventer JSJ (2017) Characterisation of one-part geopolymer binders made from fly ash. Waste Biomass Valoriz 8(1):225-233

11. Xiao J, Zuo Y, Li P, Wang J, Wu Y (2018) Preparation and characterization of straw/magnesium cement composites with highstrength and fire-retardant. J Adhes Sci Technol 4243:1-15

12. Tajvidi M, Ebrahimi G (2002) Water uptake and mechanical characteristics of natural filler-polypropylene composites. J Appl Polymer Sci 88:941-946

13. Musyoka NM, Petrik LF, Fatoba OO, Hums E (2013) Synthesis of zeolites from coal fly ash using mine waters. Minerals Eng 53:9-15

14. Rajamma R, Ball RJ, Tarelho LAC, Allen GC, Labrincha JA, Ferreira VM (2009) Characterisation and use of biomass fly ash in cementbased materials. J Hazard Mater 172:1049-1060

15. Jiang Z, Qian C, Chen Q (2017) Experimental investigation on the volume stability of magnesium phosphate cement with different types of mineral admixtures. Constr Build Mater 157:10-17

16. Bentz DP, Stutzman PE, Zunino F (2017) Low-temperature curing strength enhancement in cement-based materials containing limestone powder. Mater Struct 50(3):173

17. Osman MA, Atallah A, Suter UW (2004) Influence of excessive filler coating on the tensile properties of LDPE-calcium carbonate composites. Polymer (Guildf) 45(4):1177-1183

18. BS EN 634-2 (2007) Cement-bonded particleboards—specifications - part 2: requirements for OPC bonded particleboards for use in dry, humid and external conditions. Br Stand 2:1-12

19. Sotannde OA, Oluwadare AO, Ogedoh O, Adeogun PF (2012) Evaluation of cement-bonded particle board produced from Afzelia africana wood residues. J Eng Sci Technol 7(6):732-743

20. ASTM:D1037 (2012) Standard test methods for evaluating properties of wood-base fiber and particle panel materials. Annu B ASTM Stand 04.10:1-31

21. Ahmadi M, Vahabzadeh F, Bonakdarpour B, Mofarrah E, Mehranian M (2005) Application of the central composite design and response surface methodology to the advanced treatment of olive oil processing wastewater using Fenton's peroxidation. J Hazard Mater 123(1-3):187-195

22. Haughey D (2015) Pareto analysis step by step. https://www.proje ctsmart.co.uk/pareto-analysis-step-by-step.php. Accessed 12 Mar 2019

23. Yazaki Y, Gu R, Lin Y, Chen W, Nguyen NK (1993) Analyses of black wattle (Acacia mearnsii) tannins-relationships among the hidepowder, the stiasny and the ultra-violet (UV) methods. Holzforschung 47(1):57-61

24. Ding Z, Dong B, Xing F, Han N, Li Z (2012) Cementing mechanism of potassium phosphate based magnesium phosphate cement. Ceram Int 38(8):6281-6288

25. Makaratat N, Jaturapitakkul C, Laosamathikul T (2010) Effects of calcium carbide residue-fly ash binder on mechanical properties of concrete. J Mater Civ Eng 22(11):1164-1170

26. Wagh AS, Jeong SY (2003) Chemically bonded phosphate ceramics. J Am Ceram Soc 86(11):1838-1844

27. Xu B, Ma H, Shao H, Li Z, OthenbachL B (2017) Influence of fly ash on compressive strength and micro-characteristics of 
magnesium potassium phosphate cement mortars. Cem Concr Res 99(April):86-94

28. Chung DDL (2002) Review: improving cement-based materials by using silica fume. J Mater Sci 37(4):673-682

29. Saad M, Abo-El-Eneinf SA, Hanna GB, Kotkata MF (1996) Effect of temperature on physical and mechanical properties of concrete containing silica fume. Cem Concr Res 26(5):669-675
30. Kim S (2009) Environment-friendly adhesives for surface bonding of wood-based flooring using natural tannin to reduce formaldehyde and TVOC emission. Bioresour Technol 100(2):744-748

Publisher's Note Springer Nature remains neutral with regard to jurisdictional claims in published maps and institutional affiliations. 